Sleep Paralysis 


\section{Studies in Medical Anthropology}

Edited by Mac Marshall

\section{Advisory Board}

William Dressler

Sue E. Estroff

Peter Guarnaccia

Alan Harwood

Craig R. Janes

Sharon Kaufman

Lynn Morgan

Catherine Panter-Brick

Stacy Leigh Pigg

Lorna Rhodes 


\section{Sleep Paralysis}

Night-mares, Nocebos, and the Mind-Body Connection

SHELLEY R. ADLER

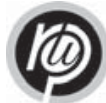

RUTGERS UNIVERSITY PRESS 


\section{LIBRARY OF CONGRESS CATALOGING-IN-PUBLICATION DATA}

Adler, Shelley R., I963-

Sleep paralysis : night-mares, nocebos, and the mind-body connection / Shelley R. Adler.

p. cm.

Includes bibliographical references and index.

ISBN 978-O-8I35-4885-2 (hardcover : alk. paper) - ISBN 978-O-8I35-4886-9 (pbk. : alk. paper)

I. Nightmares. 2. Sleep disorders. 3. Mind and body. I. Title.

BFI099.N53A44 2OII

I54.6-dc22

2010004654

A British Cataloging-in-Publication record for this book is available from the British Library.

Copyright (C) 20II by Shelley R. Adler

All rights reserved

No part of this book may be reproduced or utilized in any form or by any means, electronic or mechanical, or by any information storage and retrieval system, without

written permission from the publisher. Please contact Rutgers University Press, Ioo Joyce Kilmer Avenue, Piscataway, NJ 08854-8099. The only exception to this prohibition is "fair use" as defined by U.S. copyright law.

Visit our Web site: http://rutgerspress.rutgers.edu

Manufactured in the United States of America 
For Nancy, Sarah, Kate, Jeffrey, and Scott In memory of my mother, Shoshana Adler 
